\title{
Bifidobacterium catenulatum, Bifidobacterium dentium, and Bifidobacterium angulatum: Three New Species and Their Deoxyribonucleic Acid Homology Relationships
}

\author{
V. SCARDOVI AND F. CROCIANI
}

Istituto di Microbiologia Agraria, Universitá di Bologna, Italy

\begin{abstract}
Previous studies by us and our colleagues suggested three distinctive deoxyribonucleic acid (DNA) homology groups among the bifidobacteria; these were provisionally named "catenulatum," "dentium," and "angulatum." One hundred eighty-four strains isolated from sewage, in addition to many of the strains from the previous study, were investigated and their DNA homology relationships were assessed using 23 reference systems. Strains in the catenulatum group were found not to differ significantly from those of Bifidobacterium adolescentis Reuter in their main physiological characters, such as sugars fermented and temperature, $\mathrm{pH}$, and oxygen relationships; however, their DNA reciprocal homology is only some $50 \%$, their guanine plus cytosine values were $54.7 \pm 0.2$ and $59.4 \pm 0.4 \mathrm{~mol} \%$, respectively, and there were some morphological differences between them. The DNA of the dentium group has only about $45 \%$ homology with the DNA of $B$. adolescentis and is even less related to other members of the genus. The dentium strains can also be distinguished from other bifidobacteria by means of their sugar fermentations. The DNA of the angulatum group has little or no homology with that of any other bifidobacteria; the angulatum group also has a distinctive pattern of sugar fermentation and a unique morphology, resembling that of the coryneform bacteria. The three groups are named and described as new species of the genus Bifidobacterium: $B$. catenulatum, $B$. dentium, and $B$. angulatum. The type strains of these species are B669 (= ATCC 27539), B764 (= ATCC 27534), and B677 (= ATCC 27535), respectively. DNA-DNA homology relationships are basic to currently proposed species concepts, and data are presented confirming the reliability of critical experimental parameters influencing filter-bound DNA and thus the final relative homology values (e.g., temperature and time of incubation and annealing of DNA in the presence of homologous and heterologous competitive or nonspecific DNA, and the replicability of homology values using different homologous DNA preparations with single DNA competitor and reference DNA).
\end{abstract}

In a previous investigation (32), a large number of bifidobacteria displaying the general fermentation pattern of Bifidobacterium adolescentis Reuter were differentiated by means of deoxyribonucleic acid (DNA)-DNA hybridization into three groups, which were named "catenulatum," "dentium," and "angulatum." The angulatum group was well characterized by an unusual and constant " $V$ " or angular cell disposition, suggesting the "snapping" type of cell division of the corynebacteria. The other two groups could not easily be distinguished phenotypically from $B$. adolescentis, although strains in the group named catenulatum commonly produced cells in chains, especially in old cultures. However, only seven strains of $B$. adolescentis from Reuter's collection and another strain isolated by us from adult feces were available for study, and on the basis of DNA homology relatedness we could assign only 10 strains to the catenulatum group. The investigation of nucleic acid relatedness was later extended to over 300 strains of bifidobacteria selected from 480 isolates from sewage. Some of these strains were considered to be representative of new taxa, which will be described in a subsequent paper (30). Sixty-six strains were assigned to $B$. adolescentis, and 71 were assigned to the partially described catenulatum group; except for only 14 strains, all of 
the others were assigned to known species of the genus Bifidobacterium. Furthermore, mannitol-fermenting bifidobacteria isolated from the rumens of cattle (31) and studied by Crociani et al. (5) for DNA relatedness (groups II and III of Crociani et al.) were reinvestigated thoroughly and were identified as belonging to $B$. adolescentis.
By using both DNA-DNA hybridization and physiological tests, the boundaries between the catenulatum and dentium groups and $B$. adolescentis became more easily discernible. The catenulatum, dentium, and angulatum groups are therefore described and named as new species of the genus Bifidobacterium OrlaJensen.

TABLE 1. List of strains

\begin{tabular}{|c|c|c|}
\hline Organisms & Isolated from & $\begin{array}{l}\text { Culture received } \\
\text { from }\end{array}$ \\
\hline 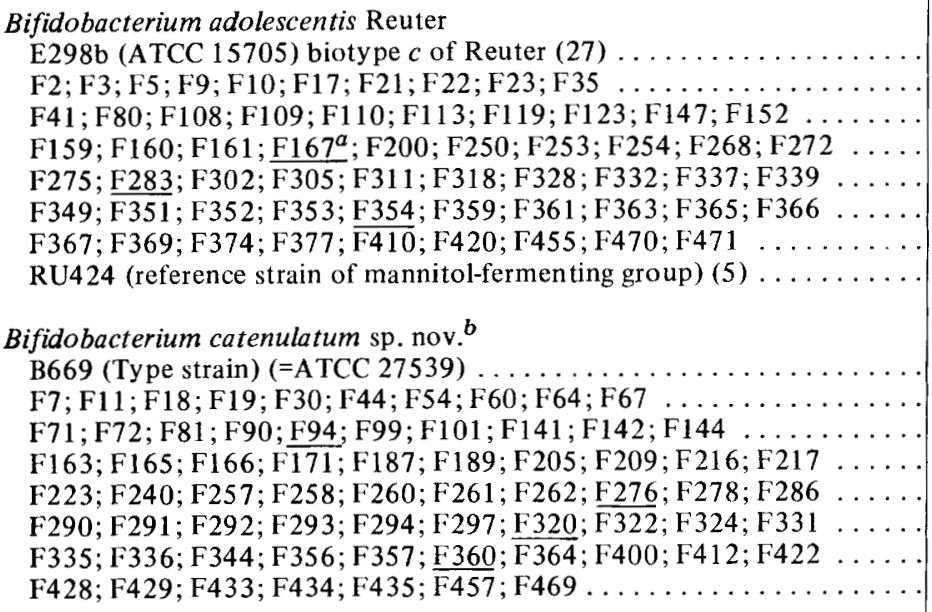 & $\begin{array}{l}\text { Feces of adult } \\
\text { Sewage } \\
\text { Sewage } \\
\text { Sewage } \\
\text { Sewage } \\
\text { Sewage } \\
\text { Sewage } \\
\text { Rumen of cattle }\end{array}$ & $\begin{array}{l}\text { Our collection } \\
\text { Our collection } \\
\text { Our collection } \\
\text { Our collection } \\
\text { Our collection } \\
\text { Our collection } \\
\text { Our collection } \\
\text { Our collection }\end{array}$ \\
\hline 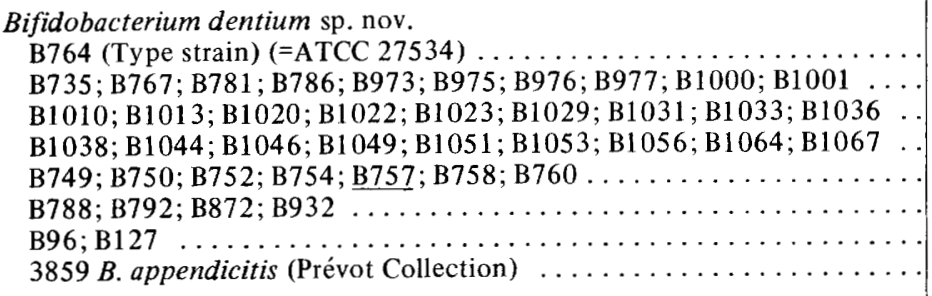 & $\begin{array}{l}\text { Dental caries } \\
\text { Dental caries } \\
\text { Dental caries } \\
\text { Dental caries } \\
\text { Feces of adult } \\
\text { Human vagina } \\
\text { Oral cavity } \\
\text { Human appendix }\end{array}$ & $\begin{array}{l}\text { Our collection } \\
\text { Our collection } \\
\text { Our collection } \\
\text { Our collection } \\
\text { Our collection } \\
\text { Our collection } \\
\text { H. Beerens } \\
\text { T. Mitsuoka }\end{array}$ \\
\hline $\begin{array}{l}\text { Bifidobacterium angulatum } \text { sp. nov. } \\
\quad \text { B677 (Type strain) }(=\text { ATCC } 27535) \ldots \ldots \ldots \ldots \ldots \ldots \ldots \ldots \ldots \ldots \ldots \ldots \ldots \ldots \ldots \ldots \ldots \ldots \ldots \ldots \ldots \ldots \ldots\end{array}$ & $\begin{array}{l}\text { Feces of adult } \\
\text { Sewage }\end{array}$ & $\begin{array}{l}\text { Our collection } \\
\text { Our collection }\end{array}$ \\
\hline 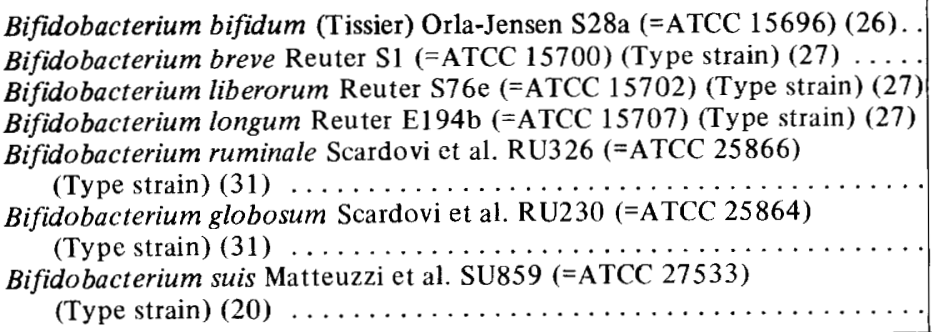 & $\begin{array}{l}\text { Feces of infant } \\
\text { Feces of infant } \\
\text { Feces of infant } \\
\text { Feces of adult } \\
\text { Rumen of cattle } \\
\text { Rumen of cattle } \\
\text { Feces of pig }\end{array}$ & $\begin{array}{l}\text { G. Reuter } \\
\text { G. Reuter } \\
\text { G. Reuter } \\
\text { G. Reuter } \\
\text { Our collection } \\
\text { Our collection } \\
\text { Our collection }\end{array}$ \\
\hline
\end{tabular}

${ }^{a}$ Underlined strains were used as additional reference systems in DNA-DNA hybridization.

$b$ The strains of $B$. catenulatum studied previously. (32) with DNA hybridization were B660, B661, B676, B684 (from feces of man), and B933 (from human vagina). 
TABLE 2. Release of filter-bound DNA after incubation at different temperatures in $0.25 \mathrm{ml}$ of Denhardt mixture in $2 \times S S C$ : DNA from $B$. ruminale $R U 326^{a}$

\begin{tabular}{|c|c|c|c|c|}
\hline \multirow[b]{3}{*}{$\begin{array}{l}\text { Incubation temp } \\
\text { (C) }\end{array}$} & \multicolumn{4}{|c|}{ DNA remaining on filter $(\%)$} \\
\hline & \multirow{2}{*}{$\begin{array}{c}\text { After } 6 \mathrm{~h} \\
\text { preincubation }\end{array}$} & \multirow{2}{*}{$\begin{array}{l}\text { After additional } 12 \\
\mathrm{~h} \text { as for annealing }\end{array}$} & \multicolumn{2}{|c|}{$\begin{array}{l}\text { After } 18 \mathrm{~h} \text { incubation } \\
\text { in presence of: }\end{array}$} \\
\hline & & & $A^{b}$ & $\mathrm{~B}^{c}$ \\
\hline 64.0 & $76.5 \pm 1.2$ & $64.3 \pm 1.3$ & & \\
\hline 69.0 & $66.3 \pm 2.7$ & $54.9 \pm 2.4$ & $52.3 \pm 0.9$ & $55.8 \pm 2.4$ \\
\hline 74.0 & $61.9 \pm 1.9$ & $38.4 \pm 0.6$ & & \\
\hline 79.0 & $38.6 \pm 2.1$ & $29.1 \pm 0.3$ & & \\
\hline
\end{tabular}

$a$ All experiments were made in quadruplicate.

${ }^{b} \mathrm{~A}=150 \mu \mathrm{g}$ of homologous sheared denatured DNA.

${ }^{c} \mathrm{~B}=150 \mu \mathrm{g}$ of heterologous sheared denatured DNA (B. globosum RU230).

\section{MATERIALS AND METHODS}

Bacterial strains. The strains employed, together with their sources, are listed in Table 1 . Many were cited in a previous paper $(32$; see Table 3$)$ as $B$. adolescentis, but most of the strains from sewage were of recent isolation. All newly acquired strains, like those previously studied, had a functional fructose-6phosphate phosphoketolase (F6PPK) and produced acetic and lactic acids but not gas from glucose; furthermore, they all consisted of anaerobic, nonmotile, gram-positive, nonsporeforming, irregularly shaped cells.

DNA preparation, filter immobilization, and duplex formation. The general procedures for growing and harvesting cells, for purifying DNA and subsequently preparing filters, for calculating homology, etc., have been previously described (32). Some DNA preparations were unsuitable as competitors, and bad filters were obtained from others, generally whenever the DNA was collected by centrifugation during the process of purification because collection by "spooling" was meager or irregular. In these cases, new batches of cells were processed until the spooling of DNA threads on stirring rods was satisfactory, and eventually filters were prepared therefrom and used as additional reference systems (see Table 1). In a few cases, DNA was prepared by the combined methods of Marmur (17), Kirby (13), and Kirby et al. (14), as suggested by De Ley et al. (6); suitable DNA was obtained, but, probably on account of the many sophisticated steps involved, its recovery was rather low. In general, this procedure seems unsuitable for routine work when many batches of cells are processed daily. In any case, the filters obtained with DNA prepared with this procedure were not superior for their binding capacities to those prepared with DNA obtained by the carefully performed Marmur procedure alone (17).

Reliability of the method. Annealing in $1 \times \mathrm{SSC}$ (18) was conducted at $69 \mathrm{C}$, i.e., $25 \mathrm{C}$ below the $T_{m}$ of the reference DNAs (near $94 \mathrm{C}$ for most bifidobacteria). It is claimed that high annealing temperatures give erroneous results in DNA homology
TABLE 3. Amounts of ${ }^{14} \mathrm{C}-D N A$ fixed in the absence of, and in the presence of, graded amounts of homologous competitor from B. globosum RU230

${ }^{1}{ }^{4} \mathrm{C}-\mathrm{DNA}$
activity fixed

Presence of competitor (counts/min)

1. Without competitor $\ldots \ldots \ldots \ldots \ldots 1,150$

2. With competitor:

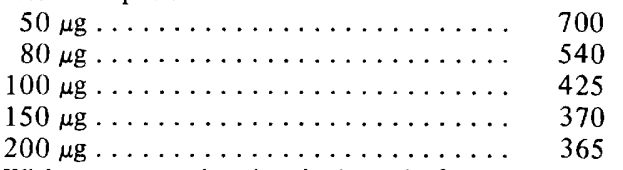

3. Without competitor but in $1.5 \mathrm{ml}$ of $3 \times$ SSC + DMSO $45 \%$ (dimethylsulfoxide method, [15]) ............

4. As in no. 3 with threefold amount of ${ }^{14} \mathrm{C}$-DNA $\ldots \ldots \ldots \ldots \ldots \ldots \ldots$

${ }^{a}$ Input, 3,600 counts/min; specific activity of ${ }^{14} \mathrm{C}$-DNA, 1,125 counts per min per g. After $6 \mathrm{~h}$ of preincubation and $12 \mathrm{~h}$ of incubation for annealing at $69 \mathrm{C}$ in $0.23 \mathrm{ml}$ of Denhardt mixture.

determinations mainly because of an excessive spontaneous release of DNA bound to filters $(2,6,23)$. Filters loaded with $14 \mu \mathrm{g}$ of ${ }^{14} \mathrm{C}$-labeled DNA of Bifidobacterium ruminale RU326 averaged 13,260 counts/min. Sets of filters were incubated under the same conditions as in our duplexing experiments but at different temperatures. A release of filter-bound DNA occurs under the conditions used in the annealing experiments $(60 \mathrm{C})$, but its magnitude, if the figures reported by De Ley and Tijtgat (7) are compared, is apparently maintained within a permissible range (Table 2). Okanishi and Gregory (23) recently observed that leaching of filter-bound DNA (from streptomycetes) can be greatly accentuated by the presence of sheared denatured DNA in solution. We tested this effect under our routine conditions using $150 \mu \mathrm{g}$ of either homologous or heterologous 
TABLE 4. Effects of the input of ${ }^{14} \mathrm{C}-\mathrm{DNA}$ on binding in the absence of competitor and on homology values with $150 \mu \mathrm{g}$ of DNA competitor from B. animalis P23 $(30)^{a}$

\begin{tabular}{c|c|c|c}
\hline & Total activity & & $\begin{array}{c}\text { Homology values } \\
\text { (with } 150 \mu \mathrm{g} \text { of } \\
\text { competitor DNA) }\end{array}$ \\
\hline $1.0 \mu \mathrm{g}$ of ${ }^{14} \mathrm{C}-\mathrm{DNA}$ & 1,440 & $\begin{array}{c}1{ }^{4} \mathrm{C}-\mathrm{DNA} \text { fixed } \\
(\%)\end{array}$ & 50 \\
$1.5 \mu \mathrm{g}$ of ${ }^{14} \mathrm{C}$-DNA & 2,160 & 30.0 & 43 \\
$3.0 \mu \mathrm{g}$ of ${ }^{14} \mathrm{C}-\mathrm{DNA}$ & 4,320 & 27.3 & 43 \\
$6.0 \mu \mathrm{g}$ of ${ }^{14} \mathrm{C}-\mathrm{DNA}$ & 8,640 & 25.6 & 38 \\
\hline
\end{tabular}

${ }^{a}$ Reference system: B. globosum RU230.

competitor DNA, but there was no increased leaching (Table 2).

The amount of competitor DNA $(150 \mu \mathrm{g})$ used in the single-point competition procedure adopted is sufficient to reach the saturation plateau (Table 3 ). The method of Legault-Démare et al. (15), in which dimethylsulfoxide (DMSO) is added to the hybridization mixture, has been advocated as giving the most reliable results (7). We observed that, probably on account of the large volume of the annealing mixture used $(1.5 \mathrm{ml})$, much larger amounts of labeled DNA are necessary for obtaining the levels of DNA fixed in the Denhardt-Johnson procedure (see last figures of Table 3). Furthermore, from the data reported by De Ley and Tijtgat (see Fig. 6 and 8 of reference 7), 400 to $700 \mu \mathrm{g}$ of competitor DNA should be used per competition experiment. The use of such large amounts of DNA is impractical whenever, as in the case in point, the same DNA preparation is used in an unpredictable number of competition experiments with more than one reference system.

In general, we recommend the use of low amounts of labeled DNA both in direct and competition annealing reactions (some 1 to $2 \mu \mathrm{g}$ ) with respect to the amount of the reference DNA fixed to the filter. Because, however, of sizeable differences in DNA labeling from one batch of cells to another (variations from 700 to 2,000 counts/min per $\mu \mathrm{g}$ of ${ }^{14} \mathrm{C}$-DNA are common under our conditions), we preferred to adjust the amount of labeled DNA to initial imputs of 3,000 to 4,500 counts/min, producing confidence on fixation levels of nearly $30 \%$. Variations in the amounts of ${ }^{14} \mathrm{C}$-DNA, such as those reported in Table 4, do not seem to affect the extent of the fixation (in the absence of competitor) nor the homology levels measured in the presence of $150 \mu \mathrm{g}$ of heterologous competitor; some deviation can be expected at low initial inputs of ${ }^{14} \mathrm{C}$-DNA (see Table 4). In certain cases, DNA competed slightly or not at all, irrespective of the reference systems used. These bad preparations were generally obtained by centrifugation instead of by spooling with a glass rod. Undue variability in the competitive effectiveness of different preparations from the same strain could not be excluded, however, since 40 to $50 \%$ of filter-fixed DNA is lost during incubation at $69 \mathrm{C}$. We assessed, therefore, the overall reproducibility of the competition method of determining homology by testing the relatedness to the same reference system of homologous and heterol-
TABLE 5. Homology values obtained with different preparations of DNA of B. globosum (RU230) and $B$. animalis (P23) (see 30) used as competitor in the same reference system (RU230)

\begin{tabular}{|c|c|}
\hline DNA competitor & $\begin{array}{l}\text { Percent homology } \\
\text { to reference DNA }\end{array}$ \\
\hline \multicolumn{2}{|l|}{ Strain RU230 prepn: } \\
\hline no. $1 \ldots \ldots$ & $100^{a}$ \\
\hline no. 2 . & $92.2 \pm 1.5$ \\
\hline no. $3 \ldots \ldots$ & $93.5 \pm 0.7$ \\
\hline no. $4 \ldots \ldots$. & $95.8 \pm 0.6$ \\
\hline no. $5 \ldots \ldots \ldots$ & . $\quad 102.1 \pm 2.1$ \\
\hline no. $6 \ldots \ldots \ldots$ & $92.0 \pm 1.3$ \\
\hline no. 7 . & $93.2 \pm 0.7$ \\
\hline no. $8 \ldots$ & $98.2 \pm 1.1$ \\
\hline \multicolumn{2}{|l|}{ Strain $\mathrm{P} 23$ prepn: } \\
\hline no. $1 \ldots \ldots \ldots$ & $40.7 \pm 1.5$ \\
\hline no. $2 \ldots \ldots \ldots$ & $43.7 \pm 3.6$ \\
\hline no. $3 \ldots \ldots \ldots \ldots$ & $33.2 \pm 4.5$ \\
\hline no. 4. & $38.7 \pm 1.7$ \\
\hline no. $5 \ldots$ & $39.7 \pm 1.2$ \\
\hline no. $6 \ldots$ & $37.2 \pm 2.5$ \\
\hline no. $7 \ldots \ldots \ldots$ & $32.7 \pm 2.2$ \\
\hline
\end{tabular}

${ }^{a}$ The value of $100 \%$ homology was calculated from the figures obtained with the DNA used for the preparation of filters. All experiments were made in quadruplicate.

ogous competitor DNAs obtained from different batches of cells of the same strains (Table 5). Provided that single filters were derived from the same mother filter, the percentage of DNA relatedness was not seriously influenced by the competitor DNA coming from different batches of cells.

DNA base composition. The thermal melting point $\left(T_{m}\right)$ of DNA dissolved in $1 \times \mathrm{SSC}$ was determined using a $T_{m}$ Analyzer (Beckman Instruments Inc.) and the mol \% of guanine plus cytosine $(\mathrm{G}+\mathrm{C})$ was calculated by the formula of Marmur and Doty (19). Ethanol-dehydrated DNA fibers were routinely spooled onto glass rods and preserved in vacuum over $\mathrm{CaCl}_{2}$ at $4 \mathrm{C}$.

Physiological characters. Trypticase (BBL)-phytone (BBL)-yeast extract (Difco)-glucose (TPY) medium 
of the composition already reported (32) was used throughout this study. Bromocresol purple $(30 \mathrm{mg} /$ liter) was used as indicator. Substrates $(0.5 \% \mathrm{wt} / \mathrm{vol})$ in the fermentation tests were autoclaved in the basal medium except for pentoses, which were sterilized by filtration and added aseptically. Growth and color changes were recorded after 8 to 10 days of incubation in anaerobic jars at $39 \mathrm{C}$.

Oxygen tolerance and $\mathrm{CO}_{2}$ requirements were determined from the growth characteristics of agar stabs and slant cultures incubated in air in closed jars to prevent evaporation, in $10 \% \mathrm{CO}_{2}$ plus $90 \% \mathrm{~N}_{2}$, and in $10 \% \mathrm{CO}_{2}$ plus $90 \%$ air. For comparative purposes only, organisms were considered to be "normally" or "highly" anaerobic if the oxygen inhibition zones were less than or greater than $5 \mathrm{~mm}$ in depth, respectively, from the surfaces of agar stabs.

Temperature relations were ascertained using the temperature gradient incubator of Oppenheimer and Drost-Hansen (24).

Acidic products from the fermentation of glucose in 7 -day-old cultures were determined. Titrations of the original broth and steam distillate were calculated as total acidity and acetic acid, respectively. Proteins were precipitated with $\mathrm{ZnSO}_{4}-\mathrm{NaOH}$, and the cleared supernatant was then steam-distilled. Lactic acid production and the configuration of the lactic acid were determined from analy ses of ethyl ether extracts using the enzymatic procedure and products of Boehringer (Biochemia, Milano). The presence of propionic and butyric acids in steam-distilled fractions was tested for by means of gas chromatography using a Perkin-Elmer model F11 instrument equipped with hydrogen flame detector. A stainless steel column $(2 \mathrm{~m}$ by $0.3 \mathrm{~cm}$ ) was packed with Trimer acid (Company source) and dinonylnaphthalenedisulfonic acid $(10 / 0.4$, wt/wt) coated on chromosorb W $(60 / 80$ mesh). The temperature of the injection block was $280 \mathrm{C}$, and the column temperature was programmed at $5 \mathrm{C}$ per min from 80 to $160 \mathrm{C}$. Volatile acids present in the steam distillate were dissolved in $5 \%$ formic acid before injection (4). Nitrogen was the carrier gas at a flow rate of $25 \mathrm{ml} / \mathrm{min}$.

Other physiological tests were as follows: ammonia from arginine or asparagine $(0.3 \% \mathrm{wt} / \mathrm{vol})$ added to TPY medium, as described by Gasser (11); urease production by incubation of a $1-\mathrm{ml}$ cell suspension in phosphate buffer $(0.1 \mathrm{~N}, \mathrm{pH} 7)$ containing $25 \mu \mathrm{mol}$ of urea and subsequent nesslerization; nitrate reduction in a modified TPY medium containing $\mathrm{KNO}_{3}$ and glucose (each $0.1 \% \mathrm{wt} / \mathrm{vol}$ ), as detected by the sulfanilic-naphthylamine reagent; and indole and acetylmethylcarbinol production by the usual tests (3).

Enzymology. Cells were mechanically disrupted by shaking with glass beads in a Nossal apparatus. The supernatant cell extracts, containing 6 to $12 \mathrm{mg}$ of protein per $\mathrm{ml}$, were assayed for aldolase by the procedure of Sibley and Lehninger (35) as modified by Dounce et al. (10), and for F6PPK as described by Schramm et al. (34). The glucose-6-phosphate dehydrogenase (G6PD) assay system contained the following: $2.6 \mathrm{ml}$ of glycyl glycine buffer, $0.1 \mathrm{M}, \mathrm{pH} \mathrm{7.5}$; $0.20 \mathrm{ml}$ of $\mathrm{MgCl}_{2}, 0.1 \mathrm{M} ; 0.1 \mathrm{ml}$ of $\mathrm{G} 6 \mathrm{P}$ sodium salt,
$0.3 \mathrm{M} ; 0.10 \mathrm{ml}$ of nicotinamide adenine dinucleotide phosphate (NADP) sodium salt, $0.03 \mathrm{M}$; and $0.01 \mathrm{ml}$ of cell extract; the final volume was $3 \mathrm{ml}$. The 6-phosphogluconate dehydrogenase (6PGD) assay system contained the following: $2.65 \mathrm{ml}$ of glycyl glycine buffer, $0.1 \mathrm{M}, \mathrm{pH} 7.6 ; 0.10 \mathrm{ml}$ of gluconate-6-P, cyclohexammonium salt, $0.3 \mathrm{M} ; 0.10 \mathrm{ml}$ of $\mathrm{MgC1}_{2}, 0.1 \mathrm{M} ; 0.10 \mathrm{ml}$ of NADP sodium salt, $0.03 \mathrm{M}$; and $0.05 \mathrm{ml}$ of cell extract; final volume, $3 \mathrm{ml}$. The G6PD and 6PGD activities were detected spectrophotometrically by change of absorbance at $340 \mathrm{~nm}$. Starch-gel electrophoresis of F6PPK was performed as previously described (29); crude cell-free extracts of $B$. bifidum S28a served as the "human" and $B$. globosum RU230 as the "animal" reference type of bifidobacterial F6PPK. Proteins were determined by the method of Lowry et al. (16). Assay compounds were obtained from Boehringer, Mannheim, Germany.

\section{RESULTS}

B. adolescentis homology group. Strains of the "catenulatum," "dentium," and "angulatum" groups exhibited fermentation patterns similar to those of biotypes $b$ and $c$ of $B$. adolescentis Reuter (26). The "angulatum" group was recognizable by its characteristic coryneformlike morphology, whereas the other two groups were, on a phenotypic basis, hardly distinguishable from $B$. adolescentis.

The study of a large number of strains forming a homogenous DNA homology group with the type strain of $B$. adolescentis was essential to an understanding of the relationships of the "catenulatum," "dentium," and "angulatum" groups to the previously described species of Bifidobacterium. Such strains were numerous among the isolates from sewage. Table 6 contains data on the DNA relatedness of 59 of these strains to five reference systems: (i) B. adolescentis Reuter E298b; (ii) B669, our reference strain for the "catenulatum" group; (iii) B764, our reference strain for the "dentium" group; (iv) B677, our reference strain for the "angulatum" group; and (v) strain RU424 (now known to be indistinct from strains of $B$. adolescentis) as representative of the mannitolfermenting bifidobacteria isolated from the rumens of cattle (31).

In a previous study (5), the DNAs from many mannitol-fermenting bifidobacteria from rumens displayed 80 to $100 \%$ homology with the DNA from strain RU424, although there were some differences in the sugars fermented (see group II and group III, p. 102, reference 5). In further DNA-DNA homology experiments, strain RU424 was highly related to some bifidobacteria isolated from human feces and having the fermentation pattern of $B$. adoles- 
centis. The present data confirm previous results and establish the DNA relatedness of strain RU424 to B. adolescentis Reuter. Furthermore, the cell wall peptidogylcan of strain RU424 contains an ornithine-(lysine)-aspartate peptide typical of that of $B$. adolescentis and quite different from those of rumen strains of $B$. globosum and $B$. ruminale (33). The DNA homogeneity of the $B$. adolescentis group was further demonstrated with many infragroup DNA-DNA hybridizations made with the additional reference systems F 167, F283, F354, and $F 420$, the data on which are not reported here. The relatedness levels of the DNAs of strains of $B$. adolescentis to the DNA reference from $B$. adolescentis strain E298b (Table 6) conclusively show the correctness of using this reference DNA to define the boundaries between our new groups and $B$. adolescentis Reuter. Among the homology values of the DNAs of the adolescentis group to the reference strain RU424, there are high values, such as 110 to $112 \%$; other similar results are reported in Table 7 . Homology values for each group were obtained from many hybridization experiments in which different DNA preparations were often used as competitors in the reference system; variability in the quality of the reference DNAs may account for such apparently atypical results.

Catenulatum homology group. Among 320 bifidobacteria from sewage, 64 strains from 36 specimens displayed high DNA relatedness to strain B669, earlier selected as the reference strain of the catenulatum group. Strains F71, F81, F94, and F99 had been studied previously (30). The data in Table 8 indicate that this important group of strains is a homogeneous assemblage whose DNA relatedness relative to other DNA reference systems distinguishes it quite sharply from B. adolescentis, B. longum, and the dentium and angulatum groups. Some strains, like F99, F240, and F257, were included in the catenulatum group because their DNAs were clearly unrelated to the DNAs from the other groups. In some runs there was only some $65 \%$ homology to the reference strain B669 (see Table 8); however, if additional DNA preparations of presumed better quality were used as competitors or references (filters), these low DNA homologies were often increased to values approaching $100 \%$. For practical reasons, however, this was done only in a limited number of cases (see underlined strains of Table 1).

Dentium homology group. Forty strains in

TABLE 6.DNA relatedness of the adolescentis group to reference DNAs from other groups or types

\begin{tabular}{|c|c|c|c|c|c|}
\hline \multirow[b]{2}{*}{ Competitor strains } & \multicolumn{5}{|c|}{ Percent homology to reference DNA from: } \\
\hline & $\begin{array}{c}\text { B. adolescentis } \\
\text { E298b }\end{array}$ & $\begin{array}{l}\text { Mannitol- } \\
\text { fermenting } \\
\text { from rumen } \\
\text { B. adolescentis } \\
\text { RU424 }\end{array}$ & $\begin{array}{c}\text { B. catenulatum } \\
\text { B669 } \\
\text { (Type strain) }\end{array}$ & $\begin{array}{c}\text { B. dentium } \\
\text { B764 } \\
\text { (Type strain) }\end{array}$ & $\begin{array}{c}\text { B. angulatum } \\
\text { B677 } \\
\text { (Type strain) }\end{array}$ \\
\hline $\mathrm{E} 298 \mathrm{~b}$ B. adolescentis & 100 & 95 & 40 & 32 & 30 \\
\hline F2;F3;F5;F9 & $90-88-83-83$ & $*-107-105-100^{a}$ & $25-30-34 * *$ & $30-36-34-*$ & $30-38-35-32$ \\
\hline F10;F17;F21;F22 & $92-85-94-88$ & $*_{-100-111-112}$ & $20-26-38-38$ & $46-23-31-32$ & $44-33-38-36$ \\
\hline F23;F35;F41;F80 & $83-100-85-98$ & $100-86-92-*$ & $34-40-32-33$ & $30-25-35-30$ & $32-*-25-35$ \\
\hline F108:F109;F110;F113 & $92-102-92-90$ & $87-97-100-87$ & $44-* 48-38$ & $30-*-31-35$ & $25-*-25-28$ \\
\hline F119;F123;F147;F152 & $85-82-90-98$ & $81-76-95-100$ & $24-40-39-41$ & $24-32-35-*$ & $26-28-30-*$ \\
\hline F159;F160;F161;F167 & $80-102-98-78$ & $75-*-94-*$ & $32-*-36-56$ & $*_{-} *_{-} *-40$ & $*_{-} *_{-} *_{-} 32$ \\
\hline F $200 ; F 250 ; F 253 ; F 254$ & $78-81-80-77$ & $71-103-92-85$ & $42-34-34-41$ & $*-49-44-32$ & $*-30-37-*$ \\
\hline F $268 ;$ F $272 ;$ F $275 ; F 283$ & $74-75-82-95$ & $*_{-} *_{-}-80-100$ & $45-40-30-25$ & $*_{-} *_{-} *_{-} *$ & $*_{-} *_{-} *_{-} *$ \\
\hline F302;F305;F311;F318 & $85-95-86-75$ & $108-87-109-76$ & $40-50-57-52$ & $42-*-40-*$ & $36-* 40-*$ \\
\hline F328;F332;F337;F339 & $82-80-75-75$ & $73-70-87-73$ & $40-30-47-27$ & $*_{-} *_{2} *_{-} *$ & $*_{-} *_{-} *_{-} *$ \\
\hline F $349 ; F 351 ; F 352 ; F 353$ & $95-72-75-102$ & $100-86-*-100$ & $52-27-45-28$ & $*_{-} *_{-} *_{-} *$ & $*_{-} *_{-} *_{-} *$ \\
\hline F354;F359;F361;F363 & $90-80-70-80$ & $94-94-87-75$ & $30-50-40-40$ & $24 *-30-25$ & $26-*-25-32$ \\
\hline F365;F366;F367;F369 & $75-77-78-70$ & $88-*-96-96$ & $54-40-41-40$ & $*_{-} *_{-} *_{-} 32$ & $*_{-} *_{-} *_{-} 25$ \\
\hline F374; F 377; F410; F420 & $80-100-85-95$ & $83-*-80-98$ & $37-30-35-30$ & $30 *-34-23$ & $31-*-*-25$ \\
\hline F $455 ; F 470 ; F 471$ & $83-70-95$ & $92-80-98$ & $30-40-30$ & $25-*-25$ & $26-*-20$ \\
\hline Range & $70-102$ & $71-112$ & $20-57$ & $24-49$ & $20-44$ \\
\hline
\end{tabular}

${ }^{a}$ Asterisk indicates not tested. 
TABLE 7. DNA relatedness of the dentium group to reference DNAs from other groups and B. longum

\begin{tabular}{|c|c|c|c|c|c|}
\hline \multirow[b]{2}{*}{ Competitor strains } & \multicolumn{5}{|c|}{ Percent homology to reference DNA from: } \\
\hline & $\begin{array}{c}\text { B. dentium } \\
\text { B764 } \\
\text { (Type strain) }\end{array}$ & $\begin{array}{c}\text { B. adolescentis } \\
\text { E298b }\end{array}$ & $\begin{array}{c}\text { B. catenulatum } \\
\text { B669 } \\
\text { (Type strain) }\end{array}$ & $\begin{array}{c}\text { B. angulatum } \\
\text { B677 } \\
\text { (Type strain) }\end{array}$ & $\begin{array}{c}\text { B. longum } \\
\text { E194b } \\
\text { (Type strain) }\end{array}$ \\
\hline B764 (Type of $/$ strain) $\mid$ B. dentium & 100 & 25 & 20 & 5 & 7 \\
\hline \multicolumn{6}{|l|}{ From feces of adult: } \\
\hline $\mathrm{B} 749 ; \mathrm{B} 750 ; \mathrm{B} 751 ; \mathrm{B} 752$ & $69-78-96-86$ & $*_{-} *_{-} *_{-} * a$ & $*_{-} *_{-} *{ }_{-} *$ & *_*_*_* & 6- 6-00-* \\
\hline $\mathrm{B} 754 ; \mathrm{B} 757 ; \mathrm{B} 758 ; \mathrm{B} 760$ & $84-92-69-85$ & $*_{-} 35-*_{-} *$ & $*_{-}-27-*_{-} *$ & $*_{-10-} *_{-} *$ & $00-5-*_{-} *$ \\
\hline \multicolumn{6}{|l|}{ From human vagina } \\
\hline B788; B792; B872; B932 & $81-77-83-105$ & $30-24-*-28$ & $25-37-*-18$ & $*_{-} *_{-} *_{-} *$ & $13-*_{-} *_{-} *$ \\
\hline \multicolumn{6}{|l|}{ From dental caries } \\
\hline $\mathrm{B} 735 ; \mathrm{B} 767 ; \mathrm{B} 781 ; \mathrm{B} 786$ & $104-101-88-110$ & $*_{-} *_{-} *_{-} *$ & $*_{-} *_{-} *_{-} *$ & $*_{-} *_{-} *_{-} *$ & $*_{-} *_{-} *_{-} *$ \\
\hline В973; В975; В976; B977 & $89-95-92-99$ & $35-33-35-*$ & $30-28-32-*$ & $15-12-14-*$ & $10-5-8-*$ \\
\hline $\mathrm{B} 1000 ; \mathrm{B} 1001 ; \mathrm{B} 1010 ; \mathrm{B} 1013$ & $102-83-97-103$ & $45-31-41-20$ & $20-25-21-19$ & $8-13-15-10$ & $2-10-6-00$ \\
\hline B1020; B1022; B1023; B1029 & $99-85-75-90$ & $30-28-28-17$ & $32-24-30-20$ & $20-15-15-12$ & $12-12-8-5$ \\
\hline B1031; B1033; B1036; B1038 & $99-108-88-106$ & $17-26-28-57$ & $16-25-31-45$ & $9-12-16-26$ & $00-4-9-12$ \\
\hline B1044; B1046; B1049; B1051 & $95-101-100-99$ & $25-42-44-30$ & $21-35-32-24$ & 14-25-18-12 & $8-13-10-4$ \\
\hline $\mathrm{B} 1053 ; \mathrm{B} 1056 ; \mathrm{B} 1064 ; \mathrm{B} 1067$ & $83-96-92-98$ & $37-23-*_{-} *$ & $32-20-*_{-} *$ & $15-8-*_{-} *$ & $6-00-*_{-} *$ \\
\hline B96; B127 (Beerens strains) & $92-81$ & $30-28$ & $30-25$ & $10-12$ & $10-10$ \\
\hline 3859 (B. appendicitis) & 83 & 25 & 19 & * & 7 \\
\hline Range & $69-110$ & $15-57$ & $16-45$ & $5-26$ & $0-13$ \\
\hline
\end{tabular}

${ }^{a}$ Asterisk indicates not tested.

TABLE 8.DNA relatedness of the catenulatum group to references from other groups and $B$. longum

\begin{tabular}{|c|c|c|c|c|c|}
\hline \multirow[b]{2}{*}{ Competitor strains } & \multicolumn{5}{|c|}{ Percent homology to reference DNA from: } \\
\hline & $\begin{array}{c}\text { B. catenulatum } \\
\text { B669 } \\
\text { (Type strain) }\end{array}$ & $\begin{array}{l}\text { B. adolescentis } \\
\text { E298b }\end{array}$ & $\begin{array}{c}\text { B. dentium } \\
\text { B764 } \\
\text { (Type strain) }\end{array}$ & $\begin{array}{c}\text { B. angulatum } \\
\text { B677 } \\
\text { (Type strain) }\end{array}$ & $\begin{array}{c}\text { B. longum } \\
\text { E194b } \\
\text { (Type strain) }\end{array}$ \\
\hline $\begin{array}{l}\text { B669 (Type strain of } \\
\text { B. catenulatum) }\end{array}$ & 100 & 40 & 32 & 22 & 20 \\
\hline F7; F11;F18; F19 & $84-93-83-88$ & $25-56-39-57$ & $20-30-36-37$ & $15-*-2-28^{a}$ & $*_{-} *_{-} 16-17$ \\
\hline F30; F44; F54; F60 & $93-82-74-95$ & $50-30-44-42$ & $37-41-37-30$ & $18-23-*_{-} *$ & $13-2-*-15$ \\
\hline F64;F67;F71;F72 & $85-92-73-70$ & $40-22-*-40$ & $32-25-28-14$ & $*_{-} *_{-} 33-*$ & $*-*-15-*$ \\
\hline $\mathrm{F} 81 ; \mathrm{F} 86 ; \mathrm{F} 90 ; \mathrm{F} 94$ & $68-83-81-78$ & $*-40-48-42$ & $34-42-35-33$ & $33-20-20-20$ & $*_{-} *_{-}-10-15$ \\
\hline F99; F101; F141; F142 & $65-83-92-71$ & $*-56-32-40$ & $21-36-29-*$ & $* \ldots 36-*$ & $*_{-} *_{-} 10-*$ \\
\hline F144;F163;F165;F166 & $100-100-85-93$ & $57-56-57-57$ & $42-48-30-*$ & $32-27-32-37$ & $00-20-3-4$ \\
\hline F171;F187;F189;F205 & $82-81-98-83$ & $30-47-50-40$ & $*_{-} *_{-} 40-35$ & $*_{-} *_{-} *_{-} 20$ & $*_{-} *_{-} *_{-} *$ \\
\hline F $209 ; F 216 ; F 217 ; F 223$ & $83-70-75-104$ & $53-30-30-54$ & $24-20-14-34$ & $*_{-} *_{-} *_{-} 38$ & $*_{-} *_{-} *_{-} 00$ \\
\hline F $240 ; F 257 ; F 258 ; F 260$ & $98-66-83-71$ & $35-40-27-38$ & $3-*_{-} *_{-}-25$ & $17-*_{-} *_{-} 10$ & $5-5-*_{-} *$ \\
\hline F261;F262;F276;F278 & $78-75-104-82$ & $37-48-45-*$ & $*_{-} *-30-*$ & $*_{-} *_{-} 20-*$ & 14-00-4-* \\
\hline F $286 ;$ F $290 ; F 291 ; F 292$ & $78-83-82-90$ & $30-35-25-*$ & $*_{-} *_{-} *_{-} 20$ & $12-*_{-} *_{-} 12$ & $13-13-*-6$ \\
\hline F293;F294;F297;F320 & $87-90-86-84$ & $*-36-45-55$ & $18-*_{-} *_{-} 33$ & $15 * *_{-} * 14$ & $8-*-26$ \\
\hline F322;F324;F331;F335 & $87-78-74-92$ & $*-51-40-50$ & $* *_{-}-25-*$ & $*_{-} *_{-} 12-*$ & $*_{-} *_{-} 00-*$ \\
\hline F336;F344;F356;F357 & $74-81-72-100$ & $*_{-} *-38-36$ & $15-*-20-*$ & $10-*_{-} *-13$ & $4-*_{-} *_{-} 36$ \\
\hline F $360 ; F 364 ; F 400 ; F 412$ & $92-67-90-67$ & $28-50-45-43$ & $20-*-25-*$ & $10-*-20-*$ & $8-00-10-*$ \\
\hline F422;F428;F429;F433 & $68-84-93-75$ & $40-*_{-} *_{-} 44$ & $*_{-} *-30-20$ & $*, *-12-8$ & $3-*-*-10$ \\
\hline F434;F435; F457;F469 & $76-81-71-72$ & $*-44-50-39$ & $20-30-30-25$ & $*_{-} *_{-1} 10-18$ & $*_{-} *-14-20$ \\
\hline Range & $65-104$ & $22-57$ & $3-48$ & $2-37$ & $0-26$ \\
\hline
\end{tabular}

\footnotetext{
${ }^{a}$ Asterisk indicates not tested.
} 
the dentium group were previously studied (32). Additional strains studied here are B96 and B127, isolated by Beerens from the oral cavity, and 3859, labeled Bifidobacterium appendicitis Prévot, received from T. Mitsuoka. The results of the study confirm previous findings (32) that this group is a separate entity. Strains from the human oral cavity previously studied by Beerens et al. (1) are homogeneous with our dentium group of strains. It is of interest to note that the strain labeled B. appendicitis 3859 from Prévot's collection also belongs to this group. However, another strain of Prévot's collection, B. appendicitis $2727 \mathrm{~B}$, has the fermentation pattern of $B$. adolescentis Reuter biotype $c$, and its DNA is fully related to the DNA of $B$. adolescentis. The general characters of these two strains of Prévot's collection bearing the label $B$. appendicitis are not those reported by Prévot (25) (Scardovi and co-workers, unpublished data). Strains belonging to the dentium group were never isolated from sewage.

Angulatum homology group. The DNA homology relationships of the strains in this group are reported in Table 9. This study confirmed previously reported results on these strains (32) and was extended to include $B$. adolescentis and $B$. longum. Unfortunately, we were unable to find new strains of the angulatum group among the recent isolates from sewage or other habitats, but the six strains studied had an unusual coryneform-like morphology, and their DNA behaved distinctively in having little or no homology with the DNAs of other bifidobacteria.

Relatedness of the catenulatum, dentium, and angulatum groups to the named species of Bifidobacterium. DNA homologies between ty pe strains of the novel groups and type strains of the known species of the genus Bifidobacterium (except those isolated from the intestine of bees) were investigated. The reference DNAs were from: $B$. bifidum strain $\mathrm{S} 28 \mathrm{a} ; B$. liberorum $\mathrm{S76e}$ for the group liberorum-infantislactentis; $B$. breve $\mathrm{S} 1$ for the group breveparvulorum; $B$. globosum RU230 for the group globosum-pseudolongum, and $B$. ruminale RU326 as representative of the ruminale-thermophilum group (32); B. longum E194b; and

TABLE 9. DNA relatedness of the angulatum group to reference DNAs from other groups and B. longum

\begin{tabular}{l|c|c|c|c|c}
\hline & \multicolumn{5}{|c}{ Percent homology to reference DNA from: } \\
\cline { 2 - 6 } & $\begin{array}{c}\text { B. angulatum } \\
\text { B677 } \\
\text { (Type strain) }\end{array}$ & $\begin{array}{c}\text { B. catenulatum } \\
\text { B669 } \\
\text { (Type strain) }\end{array}$ & $\begin{array}{c}\text { B. dentium } \\
\text { B764 } \\
\text { (Type strain) }\end{array}$ & $\begin{array}{c}\text { B. adolescentis } \\
\text { E298b }\end{array}$ & $\begin{array}{c}\text { B. longum } \\
\text { E194b } \\
\text { (Type strain) }\end{array}$ \\
\hline $\begin{array}{l}\text { B677 (Type strain of } \\
\text { B. angulatum) }\end{array}$ & 100 & 20 & 15 & 25 & 8 \\
$\begin{array}{l}\text { F158; F196; F406 } \\
\text { F424; F426 }\end{array}$ & $95-90-80$ & $30-35-35$ & $15-8-10$ & $25-30-28$ & $13-6-8$ \\
Range & $76-83$ & $25-20$ & $15-20$ & $22-20$ & $12-10$ \\
\hline
\end{tabular}

TABLE 10.DNA relatedness of type strains of the new species to type strains of the known species of the genus Bifidobacterium used as references

\begin{tabular}{|c|c|c|c|c|c|c|c|}
\hline \multirow[b]{2}{*}{ Competitor strains } & \multicolumn{7}{|c|}{ Percent homology to reference DNA from: } \\
\hline & $\begin{array}{l}\text { B. bifidum } \\
\text { S28a }\end{array}$ & $\begin{array}{c}\text { B. liberorum } \\
\text { S76e } \\
\text { (Type strain) }\end{array}$ & $\begin{array}{l}\text { B. breve } \\
\text { S1 } \\
\text { (Type } \\
\text { strain) }\end{array}$ & $\begin{array}{l}\text { B. longum } \\
\text { E194b } \\
\text { (Type } \\
\text { strain) }\end{array}$ & $\begin{array}{l}\text { B. globosum } \\
\text { RU230 } \\
\text { (Type strain) }\end{array}$ & $\begin{array}{l}\text { B. ruminale } \\
\text { RU326 } \\
\text { (Type } \\
\text { strain) }\end{array}$ & $\begin{array}{l}\text { B. suis } \\
\text { SU859 } \\
\text { (Type } \\
\text { strain) }\end{array}$ \\
\hline $\begin{array}{c}\text { B669 (Type strain of } \\
\text { B. catenulatum) }\end{array}$ & 20 & 15 & 10 & 12 & 5 & 20 & 25 \\
\hline $\begin{array}{l}\text { B764 (Type strain of } \\
\text { B. dentium) }\end{array}$ & 5 & 20 & 12 & 7 & 12 & 20 & 20 \\
\hline $\begin{array}{l}\text { B677 (Type strain of } \\
\text { B. angulatum) }\end{array}$ & 7 & 20 & 10 & 8 & 20 & 18 & 20 \\
\hline
\end{tabular}


B. suis SU859. The type strains of the proposed three new species share only a small number of polynucleotide sequences with DNA of the reference strains used (Table 10).
Distinctive phenotypic characters of the groups. (i) Morphology. The general morphology of the cells of the three groups and their arrangement are given in Plates 1, 2, and 3 .
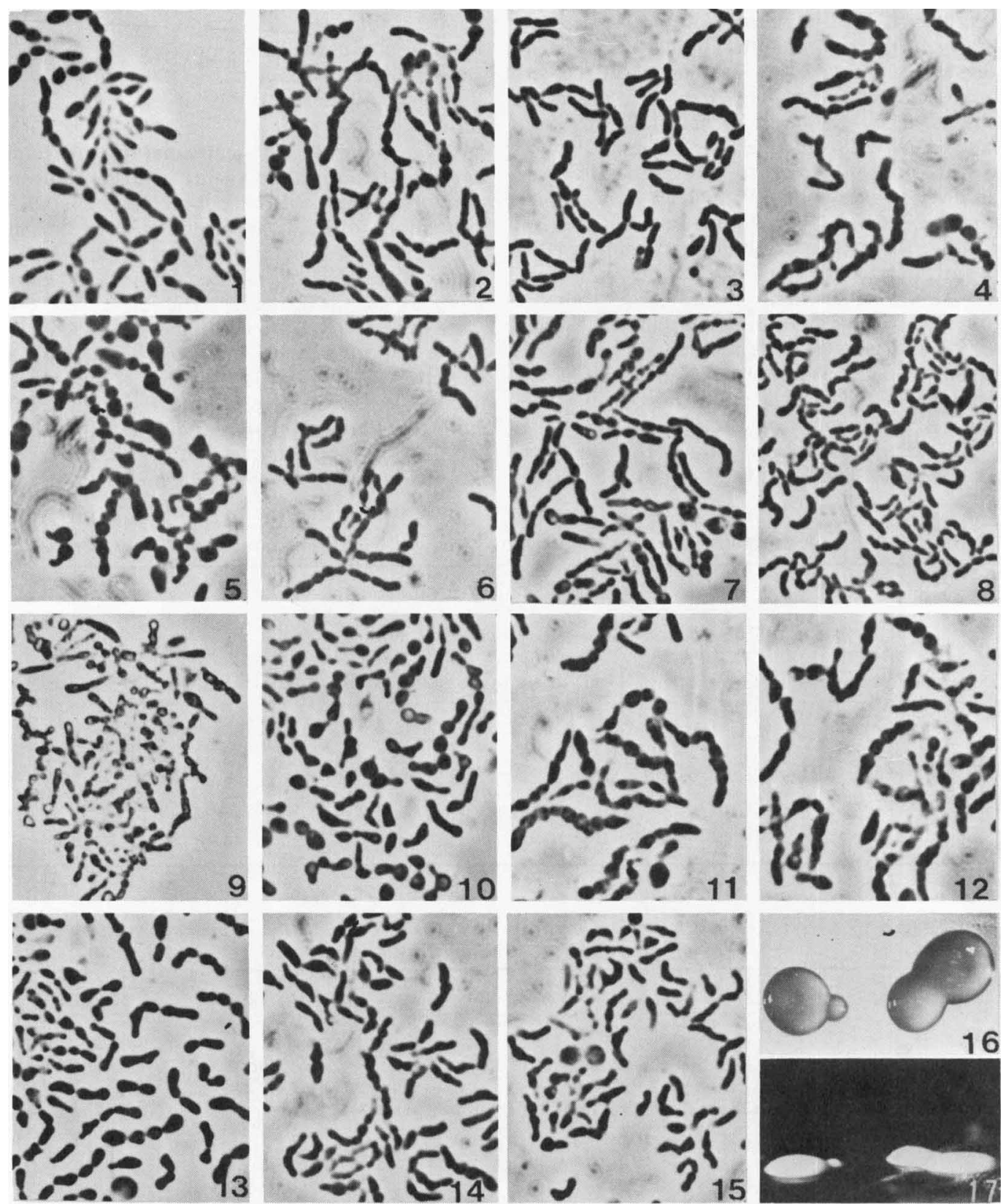

PLATE 1. Morphology of Bifidobacterium catenulatum sp. n. Fig. 1 and 2. Cells of the type strain (B669) from fresh anaerobic stabs. Fig. 3. Cells of strain B669 from a broth culture (DNA extraction). Fig. 4. Cells of strain B660 from an old anaerobic stab. Fig. 5 to 15. Cells from 2-day-old anaerobic stabs of strains B684, F60, F71, F81, F99, F141, F141, F335, F428, and F429, respectively. Phase contrast. $\times 1,500$. Fig. 16. Surface colonies of strain B669 in a slant culture incubated anaerobically under carbon dioxide. Fig. 17. Same as Fig. '16, side view. 


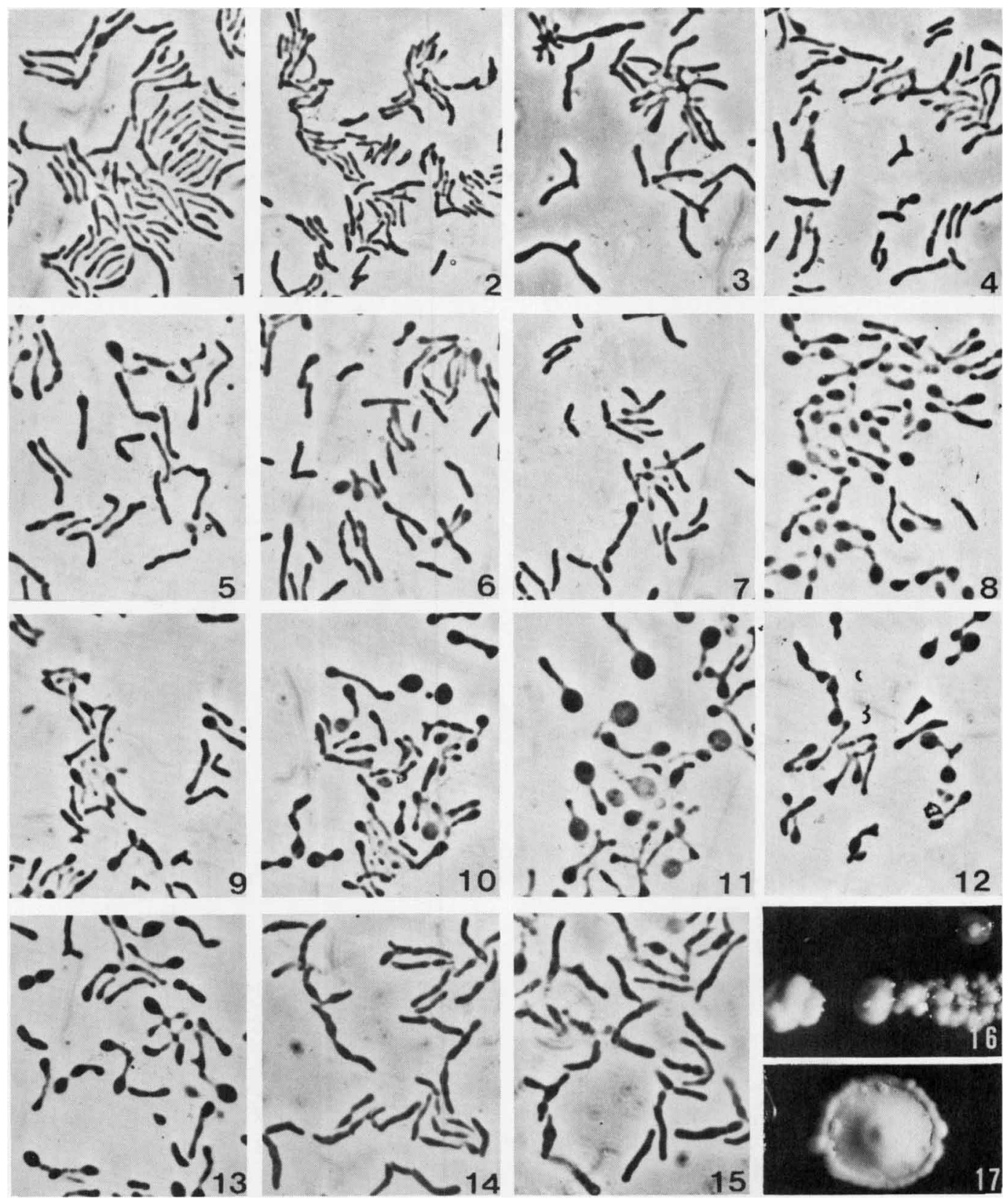

PLATE 2. Morphology of Bifidobacterium dentium sp. n. Fig. 1 and 2. Cells of the type strain (B764) from a fresh anaerobic stab and from a broth culture (DNA extraction). Fig. 3. Cells of strain $B 975$ from a broth culture (DNA extraction). Fig. 4 to 7. Cells of strains B1000, B1001, B1022, and B1029, respectively, from fresh anaerobic stabs. Fig. 8 to 13. Cells of strains B1031, B1033, B1036, B1049, B1051, and B1038, respectively, from 4-day-old anaerobic stabs. Fig. 14 and 15. Cells of strain B96 (Beerens) and B127 (Beerens), respectively, from fresh stabs. Phase contrast. $\times 1,500$. Fig. 16 and 17. Surface colonies in slants incubated anaerobically under carbon dioxide.

Arrangement in irregular chains, especially in the first transfers or in aged cultures (4 to 5 days) is characteristic of the cells of the catenulatum group. The cells of angulatum strains can be promptly recognized from their "V-" or "palisade-" like disposition, which has never been observed by us among some thousands of other bifidobacteria. The mor- 


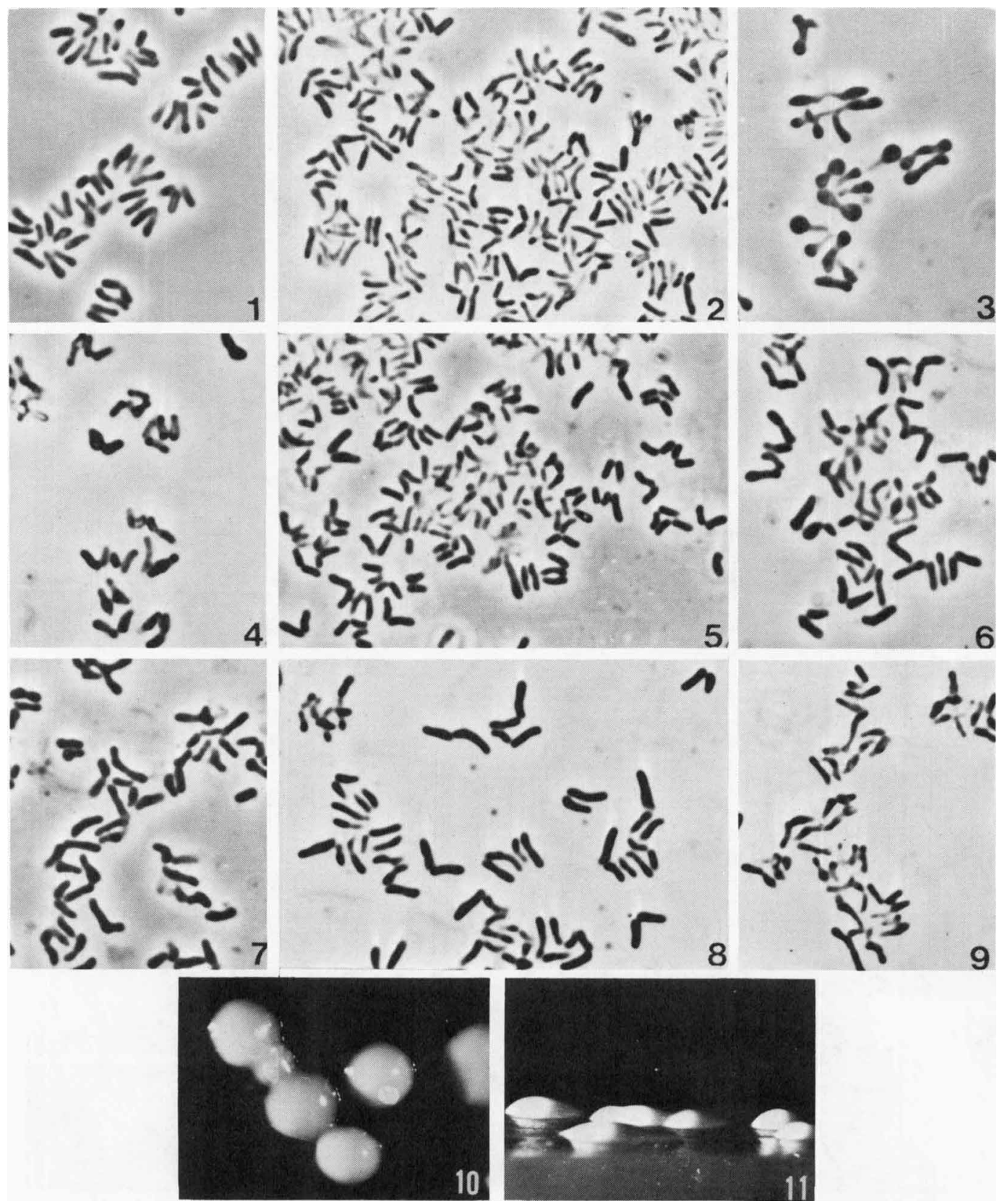

PLATE 3. Morphology of Bifidobacterium angulatum sp. n. Fig. 1 and 2. Cells of the type strain (B677) from fresh anaerobic stabs. Fig. 3. Cells of strain B677 from an 8-day-old broth culture. Fig. 4 and 5. Cells of strain F158 from broth cultures with glucose and gluconate, respectively. Fig. 6. Cells of strain F196 from a 24-h-old broth culture used for DNA extraction. Fig. 7 and 8. Cells of strain F424 from fresh anaerobic stabs. Fig. 9. Cells of strain F426 from an old anaerobic stab. Phase contrast. $\times 1,500$. Fig. 10 and 11. Surface colonies in slants incubated anaerobically under carbon dioxide.

phology of dentium cells is not characteristic; it is in general very similar to that of $B$. longum (our unpublished data).

(ii) Fermentation patterns. The sugars which are fermented by the groups are reported in Table 11. Group catenulatum cannot be distinguished on this basis from $B$. adolescentis biotype $c$ of Reuter (26): most strains ferment 
TABLE 11. Fermentation patterns of $B$. catenulatum, B. dentium, and B. angulatum and of their type strains ${ }^{a}$

\begin{tabular}{|c|c|c|c|c|c|c|}
\hline \multirow[b]{2}{*}{ Compounds } & \multicolumn{2}{|c|}{ B. catenulatum } & \multicolumn{2}{|c|}{ B. dentium } & \multicolumn{2}{|c|}{ B. angulatum } \\
\hline & 68 strains & $\begin{array}{c}\text { Type strain } \\
\text { (ATCC } \\
27539 \text { ) }\end{array}$ & 44 strains & $\begin{array}{c}\text { Type strain } \\
\text { (ATCC } \\
27534 \text { ) }\end{array}$ & 6 strains & $\begin{array}{c}\text { Type strain } \\
\text { (ATCC } \\
27535 \text { ) }\end{array}$ \\
\hline D-Xylose $\ldots \ldots$ & $t^{b}(66 / 68)^{c}$ & + & $+(44 / 44)$ & + & $+(6 / 6)$ & + \\
\hline D-Ribose ..... & & + & $+(44 / 44)$ & - & $+(6 / 6)$ & + \\
\hline D-Mannose. & $-(44 / 68)^{e}$ & - & $+(44 / 44)$ & + & $-(6 / 6)$ & - \\
\hline D-Cellobiose & $+(66 / 68)^{f}$ & + & $+(44 / 44)$ & - & $-(5 / 6)^{f}$ & - \\
\hline D-Trehalose . & $+(43 / 68)^{g}$ & - & $+(44 / 44)$ & + & $-(6 / 6)$ & - \\
\hline Melezitose . & $-(65 / 68)^{h}$ & - & $+(42 / 44)^{m}$ & + & $-(6 / 6)$ & - \\
\hline Dextrin .. & $+(36 / 68)$ & + & $+(44 / 44)$ & + & $+(6 / 6)$ & + \\
\hline Starch . & $\left.+(35 / 68)^{i}\right\}$ & + & $+(44 / 44)$ & + & $+(6 / 6)$ & + \\
\hline Inulin . & $+(35 / 68))$ & - & $-(44 / 44)$ & + & $+(6 / 6)$ & + \\
\hline Mannitol & $-(57 / 68)^{j}$ & - & $+(42 / 44)^{n}$ & + & $-(6 / 6)$ & - \\
\hline Sorbitol. & $+(66 / 68)^{k}$ & + & $-(43 / 44)^{o}$ & + & $-(5 / 6)^{q}$ & - \\
\hline Gluconate & $+(52 / 68)^{l}$ & + & $+(44 / 44)$ & + & $-(4 / 6)^{r}$ & - \\
\hline
\end{tabular}

${ }^{a}$ All strains fermented arabinose, glucose, fructose, galactose, sucrose, maltose, lactose, melibiose, raffinose, and salicin. None fermented glycerol, rhamnose, or lactate.

$b+$, fermented; - , not fermented.

${ }^{c}$ F99 and F94 were negative. The type strain (ATCC 27539) occasionally fermented arabinose and xylose slowly; this behavior was observed in B. catenulatum strains isolated from human feces and vagina (see Table 1).

${ }^{d}$ Only the strains from human feces and vagina were tested (see Table 1 ).

e F19, F30, F54, F72, F86, F90, F101, F142, F163, F166, F209, F217, F223, F240, F257, F258, F260, F322, F331, F356, F400, F434, and F435 were negative.

$f_{F} 262$ and $\mathrm{F} 508$ were negative.

F30, F141, F163, F187, F189, F205, F216, F257, F262, F286, F291, F292, F293, F297, F320, F324, F344, F364, F422, F428, F433, F434, F457, F469, and B669 (ty pe strain) were negative.

${ }^{h} \mathrm{~F} 322, \mathrm{~F} 331$, and $\mathrm{F} 435$ were positive.

$i$ Twenty strains fermented these three carbohydrates; 15 strains did not ferment any; 17 strains fermented starch and dextrin but not inulin; 16 strains fermented only inulin.

${ }_{j} \mathrm{~F} 19, \mathrm{~F} 71$, F90, F99, F189, F209, F262, F293, F336, F364, and F469 were positive.

${ }^{k} \mathrm{~F} 336$ and F457 were negative. ${ }^{l} \mathrm{~F} 18, \mathrm{~F} 54, \mathrm{~F} 72, \mathrm{~F} 86, \mathrm{~F} 101, \mathrm{~F} 187, \mathrm{~F} 257, \mathrm{~F} 262, \mathrm{~F} 322, \mathrm{~F} 331, \mathrm{~F} 336, \mathrm{~F} 400$,

$\mathrm{F} 434, \mathrm{~F} 435, \mathrm{~F} 457$, and F469 were negative.

$m$ B781 and B1000 were negative.

${ }^{n} \mathrm{~B} 788$ and $\mathrm{B} 1000$ were negative.

B767 was positive.

${ }^{p}$ F406 was positive.

${ }^{q}$ F406 was positive.

$r_{\mathrm{F} 158 \text { and } \mathrm{F} 196 \text { were positive. }}$

sorbitol and not mannitol. The data obtained by W.E.C. Moore (personal communication) with 20 strains of the group and with the following additional compounds-adonitol, amygdalin, dulcitol, erythritol, esculin, glycogen, inositol, and sorbose-were of no help in distinguishing this group from $B$. adolescentis. The dentium strains, including strains B96 and B127 from $H$. Beerens, had a more uniform pattern, corresponding to that of $B$. adolescentis biotype $b$ (26): they fermented mannitol but not sorbitol. B. appendicitis strain B859 fermented sorbitol slowly. However, in contrast with the strains of $B$. adolescentis biotype $b$, the majority of the dentium strains fermented melezitose. The fermentation pattern of the angulatum strains is like that of strains of biotype $b$ of $B$. adolescentis (26).
Physiological and biochemical characters. Very few differences in the physiological and biochemical characters of the groups, reported in the detailed descriptions below, are apparent: dentium strains can develop at somewhat lower temperatures ( $24 \mathrm{C}$ instead of 28 to 29 C); angulatum strains are more sensitive to free oxygen, and their anaerobic growth is highly stimulated by the presence of $\mathrm{CO}_{2}$. However, a difference of more weight was revealed in the DNA base composition: the $G+C$ values of strains of the catenulatum group, which range from 54.2 to $55.7 \mathrm{~mol} \%$, are significantly lower than those found in most bifidobacteria ( 59 to $61 \mathrm{~mol} \%$ ).

Because DNA homology was taken as a guideline in our studies on the speciation of the genus Bifidobacterium, the data presented here 
concerning the DNA homology relationships between our three groups of strains and the previously described species of the genus constitute the principal argument on which our proposal of recognizing these groups as new species is based. Morphology and DNA base composition provide additional distinctive characters of importance for the catenulatum and angulatum groups; the strains of the dentium group did not display any distinctive phenotypic character. However, the phenotypic expression of the large divergencies in the DNA base sequences shown to exist among the species of the genus Bifidobacterium (see reference 32) remains to be discovered.

Detailed descriptions of the three new species of the genus Bifidobacterium follow.

1. Bifidobacterium catenulatum sp. n. (M.L. adj. catenulatus having small chains).

Cell characteristics. Gram-positive, nonmotile, nonsporeforming cells, generally with three to four globular elements arranged in chains 1.3 to $1.7 \mu \mathrm{m}$ in diameter; when not fragmented, the chains are 0.6 to 0.8 by 2.0 to $4.0 \mu \mathrm{m}$. The distal ends of the chains are usually tapered. Distinct branchings, club-swellings, or spatula-like extremities are generally absent. (Plate 1, Fig. 1-15)

Surface colonies. Smooth, convex, entire edges, cream to white, glistening and soft. (Plate 1, Fig. 16 and 17)

Relationships to oxygen and $\mathrm{CO}_{2}$. Anaerobic; $\mathrm{CO}_{2}$ is without affect upon oxygen sensitivity or anaerobic growth.

Temperature relationships. Optimum, 39 to $41 \mathrm{C}$; minimum, 28 to $28.5 \mathrm{C}$; maximum, 42.5 to $43 \mathrm{C}$; no growth at $26 \mathrm{C}$ or $44 \mathrm{C}$.

pH relationships. Initial optimum, 6.5 to 6.9 ; delayed growth at 6.3 or 7.2 ; no growth at 4.5 or 8.0 .

End products from glucose. Lactic and acetic acids in a molar ratio of $1: 2.15 \pm 0.15$ are produced in TPY medium. Isomeric type of lactic acid produced: $\mathrm{L}(+) . \mathrm{CO}_{2}$ is formed only in the fermentation of gluconate.

Fermentation pattern. The fermentation pattern is given in Table 11. Most strains (approximately $85 \%$ ) ferment sorbitol but not mannitol, as do strains of biotype $c$ of $B$. adolescentis Reuter.

Enzymology. Fructose-1,6-diphosphate aldolase: $<2 \mathrm{mU}$ of specific activity; G6P dehydrogenase $\left(\mathrm{NAD}^{+}\right.$or $\mathrm{NADP}^{+}$dependent) not demonstrable; $6 \mathrm{PG}$ dehydrogenase (NADP ${ }^{+}$ dependent): some $40 \mathrm{mU}$ of specific activity; electrophoretic type of F6PPK: "human."

Biochemical reactions. Catalase or pseudo- catalase (hemin) not produced; nitrate not reduced; indole not produced; acetylmethylcarbinol produced; gelatin not liquefied; skim milk acidified and coagulated; ammonia produced from asparagine but not from urea or arginine.

G + C content of DNA. $54.7 \pm 0.2 \mathrm{~mol} \%$ $\left(T_{m}\right)$.

DNA homology relationships. More related to $B$. adolescentis Reuter (some $45 \%$ homology) than to any other species of the genus.

Source. Feces of adult man, human vagina, and sewage.

Type strain. B669 of the Collection of the Istituto di Microbiologia Agraria, Universita di Bologna, Italia; deposited in the American Type Culture Collection (ATCC), Rockville, Md. under the number 27539.

2. Bifidobacterium dentium sp. n. (L. mas. $\mathrm{n}$. dens tooth; L. plural gen. n. dentium of teeth).

Cell characteristics. Gram-positive, nonmotile, nonsporeforming, slender rods 2 to 8 $\mu \mathrm{m}$ long, with the extremities often swollen, dumb-bell shaped or enlarged to give a spatulalike appearance; branchings occur at the distal ends of the cells; chains of globular elements are absent. The general morphology is similar to that of B. longum Reuter. (Plate 2, Fig. 1-15)

Surface colonies. Flat or umbonate when aged, with entire or undulate margins, often raised, glistening, cream to white, soft. (Plate 2, Fig. 16 and 17)

Relationships to oxygen and $\mathrm{CO}_{2}$. Anaerobic; $\mathrm{CO}_{2}$ does not affect sensitivity to oxygen or anaerobic growth.

Temperature relationships. Optimum, 39 to $41 \mathrm{C}$; minimum, 24 to $25 \mathrm{C}$; maximum, 42 to $42 \mathrm{C}$; no growth at 23 or $44 \mathrm{C}$.

pH relationships. Initial optimum, 6.5 to 6.9 ; delayed growth at 6.3 or 7.2 ; no growth after two days at 4.5 or 8.0 .

End products from glucose. Lactic and acetic acids in a molar ratio of $1: 2.5 \pm 0.2$ are produced in TPY medium. Isomeric type of lactic acid produced: $\mathrm{L}(+) . \mathrm{CO}_{2}$ is formed only in the fermentation of gluconate.

Fermentation pattern. The fermentation pattern is given in Table 11. Most strains (approximately $90 \%$ ) ferment mannitol but not sorbitol and can be distinguished from strains of biotype $b$ of $B$. adolescentis Reuter because they ferment melezitose.

Enzymology. Fructose-1,6-diphosphate aldolase: $<2 \mathrm{mU}$ of specific activity; G6P dehydrogenase $\left(\mathrm{NAD}^{+}\right.$or $\mathrm{NADP}^{+}$dependent) not demonstrable; 6PG dehydrogenase (NADP $^{+}$ dependent): approximately $2 \mathrm{mU}$ of specific 
activity; electrophoretic type of F6PPK: "human."

Biochemical reactions. Catalase or pseudocatalase (hemin) not produced; nitrate not reduced; indole not produced; acetylmethylcarbinol produced; ammonia produced from asparagine but not from urea or arginine.

G + C content of DNA. $61.2 \pm 0.4 \mathrm{~mol} \%$ $\left(T_{m}\right)$.

DNA homology relationships. Insignificantly related (some $30 \%$ ) to $B$. adolescentis, $B$. catenulatum, $B$. infantis, $B$. liberorum, $B$. lactentis, $B$. ruminale, and $B$. suis; still less related or not at all to the other species of the genus Bifidobacterium.

Source. The only bifidobacterium found in human dental caries; present in human feces (adults) and the human vagina.

Type strain. B764 of the Collection of the Istituto di Microbiologia Agraria, Universita di Bologna, Italia; deposited in the ATCC under the number 27534.

3. Bifidobacterium angulatum $\mathrm{sp}$. $\mathrm{n}$. (L part. adj. angulatus with angles, angular).

Cell characteristics. Gram-positive, nonmotile, nonsporeforming cells, 0.6 to 0.7 by 1.5 to $3.0 \mu \mathrm{m}$, generally disposed in " $\mathrm{V}$ " or "palisade" arrangements like the corynebacteria; rarely enlarged at the extremities; branchings are absent. This morphological type is unique among the known species of the genus Bifidobacterium. (Plate 3, Fig. 1-9)

Surface colonies. Circular, pulvinate, smooth with entire margins, porcelain white, glistening, and of soft consistency. (Plate 3, Fig. 10 and 11)

Relationships to oxygen and $\mathrm{CO}_{2}$. Anaerobic, but more sensitive to oxygen than most bifidobacteria (from the depth of growth in stabs); $\mathrm{CO}_{2}$ does not affect the sensitivity to oxygen, but it strongly enhances anaerobic growth.

Temperature relationships. Optimum, 39 to $40 \mathrm{C}$; maximum, 42 to $42 \mathrm{C}$; minimum, 28 to $29 \mathrm{C}$; no growth at 27 or $44 \mathrm{C}$.

pH relationships. Initial optimum, 6.5 to 6.9 ; delayed growth at 6.3 or 7.2 ; no growth after two days at 4.5 or 8.0 .

End products from glucose. Lactic and acetic acids in a molar ratio of $1: 2.2 \pm 0.06$ are produced in TPY medium. Isomeric type of lactic acid produced: $L(+)$. Propionic and butyric acids not produced. $\mathrm{CO}_{2}$ is formed only in the fermentation of gluconate.

Fermentation pattern. The fermentation pattern is given in Table 11.

Enzymology. Fructose-1,6-diphosphate aldo- lase: $<2 \mathrm{mU}$ of specific activity; G6P dehydrogenase $\left(\mathrm{NAD}^{+}\right.$or $\mathrm{NADP}^{+}$dependent) not demonstrable; 6PG dehydrogenase (NADP ${ }^{+}$ dependent): approximately $10 \mathrm{mU}$ of specific activity; electrophoretic type of F6PPK: "human."

Biochemical reactions. Catalase or pseudocatalase (hemin) not produced; nitrate not reduced; indole not produced; acetylmethylcarbinol produced; gelatin not liquefied; skim milk acidified and coagulated; ammonia not produced from urea, arginine, or asparagine.

G + C content of DNA. $59.0 \pm 0.1 \mathrm{~mol} \%$ $\left(T_{m}\right)$.

DNA homology relationships. Very little or no relationship to the other known species of the genus Bifidobacterium.

Source. First isolated from human feces and then found in sewage.

Type strain. B677 of the Collection of the Istituto di Microbiologia Agraria, Universita di Bologna, Italia; deposited in the ATCC under the number 27535 .

\section{ACKNOWLEDGMENTS}

We are grateful to W. E. C. Moore, Virginia Polytechnic Institute and State University, Anaerobe Laboratory, Blacksburg, Va., for invaluable information on the phenotypic characters of a large number of our isolates.

The technical assistance of N. Vincenzi is gratefully acknowledged.

This investigation was supported by a research grant from Consiglio Nazionale delle Ricerche, Roma.

\section{REPRINT REQUESTS}

Address reprint requests to: Dr. V. Scardovi, Istituto di Microbiologia Agraria, Università di Bologna, Italia.

\section{LITERATURE CITED}

1. Beerens, H., A. Gérard, and J. Guillaume. 1957. Etude de 30 souches de Bifidobacterium bifidum (Lactobacillus bifidus). Caractérisation d'une variété buccale. Comparaison avec les souches d'origine fécale. Ann. Inst. Pasteur 9:77-85.

2. Bonner, J., G. Kung, and I. Bekhor. 1967. A method for the hybridization of nucleic acid molecules at low temperature. Biochemistry 6:3650-3653.

3. Conn, H. J., and M. W. Jennison (ed). 1957. Manual of microbiological methods. McGraw Hill, New York.

4. Cottyn, B. G., and C. V. Boucque. 1968. Rapid method for the gas-chromatographic determination of volatile fatty acids in rumen fluid. J. Agr. Food Chem. 16:105-107. 
5. Crociani, F., V. Scardovi, and L. D. Trovatelli. 1970. Mannitol fermenting bifids from rumen and their DNA homology relationships. Ann. Microbiol. 20:99-106.

6. De Ley, J., H. Cattoir, and A. Reynaerts. 1970. The quantitative measurement of DNA hybridization from renaturation rates. Eur. J. Biochem. 12:133-142.

7. De Ley, J., and R. Tijtgat. 1970. Evaluation of membrane filter methods for DNA-DNA hybridization. Antonie van Leeuwenhoek J. Microbiol. Serol. 36:461-474.

8. Denhardt, D. T. 1966. A membrane-filter technique for the detection of complementary DNA. Biochem. Biophys. Res. Commun. 23:641-646.

9. de Vries, W., S. J. Gerbrandy, and A. H. Stouthamer. 1967. Carbohydrate metabolism in Bifidobacterium bifidum. Biochim. Biophys. Acta 136:415-425.

10. Dounce, A. L., S. R. Barnett, and G. T. Beyer. 1950. Further studies on the kinetics and determination of aldolase. J. Biol. Chem. 185:769-780.

11. Gasser, F. 1964. Identification des Lactobacillus fécaux. Ann. Inst. Pasteur 106:778-796.

12. Johnson, J. L., and E. J. Ordal. 1968. Deoxyribonucleic acid homology in bacterial taxonomy: effect of incubation temperature on reaction specificity. J. Bacteriol. 95:893-900.

13. Kirby, K. S. 1957. A new method for the isolation of deoxyribonucleic acids: evidence on the nature of bonds between deoxyribonucleic acid and protein. Biochem. J. 66:495-504.

14. Kirby, K. S., E. Fox-Carter, and M. Guest. 1967. Isolation of deoxyribonucleic acid and ribosomal ribonucleic acid from bacteria. Biochem. J. 104:258-262.

15. Legault-Démare, J., B. Desseaux, T. Heyman, S. Seror, and G. P. Ress. 1967. Studies on hybrid molecules of nucleic acids. I. DNA-DNA hybrids on nitrocellulose filters. Biochem. Biophys. Res. Commun. 28:550-557.

16. Lowry, O. H., N. J. Rosebrough, A. L. Farr, and R. J. Randall. 1951. Protein measurement with the Folin phenol reagent. J. Biol. Chem. 193:265-275

17. Marmur, J. 1961. A procedure for the isolation of deoxyribonucleic acid from microorganisms. $J$. Mol. Biol. 3:208-218.

18. Marmur, J., and P. Doty. 1961. Thermal renaturation of deoxyribonucleic acids. J. Mol. Biol. 3:585-594

19. Marmur, J., and P. Doty. 1962. Determination of the base composition of deoxyribonucleic acid from its thermal denaturation temperature. J. Mol. Biol. 5:109-118.

20. Matteuzzi, D., F. Crociani, G. Zani, and L. D. Trovatelli. 1971. Bifidobacterium suis n.sp.: a new species of the genus Bifidobacterium isolated from pig feces. Z. Allg. Mikrobiol. 11:387-395.

21. McCarthy, B. J., and E. T. Bolton. 1963. An approach to the measurement of genetic related- ness among organisms. Proc. Nat. Acad. Sci. U.S.A. 50:156-164.

22. Mitsuoka, T. 1969. Vergleichende Untersuchungen über die Bifidobakterien aus dem Verdauungstrakt von Menschen und Tieren. Zentralbl. Bakteriol. Parasitenk. Infektionskr. Hyg. Abt. I Orig. 210:52-64.

23. Okanishi, M., and K. F. Gregory. 1970. Methods for the determination of deoxyribonucleic acid homologies in Streptomyces. 104:1086-1094.

24. Oppenheimer, C. H., and W. A. Drost-Hansen. 1960. A relationship between multiple temperature optima for biological systems and the properties of water. J. Bacteriol. 80:21-24.

25. Prévot, A. R., A. Turpin, and P. Kaiser. 1967. Les bactéries anaérobies. Dunod, Paris.

26. Reuter, G. 1963-64. Vergleichende Untersuchungen über die Bifidus-Flora im Sauglings- und Erwachsenenstuhl. Zentralbl. Bakteriol. Parasitenk. Infektionskr. Hyg. Abt. I Orig. 191:486-507.

27. Reuter, G. 1971. Designation of type strains for Bifidobacterium species. Int. J. Syst. Bacteriol. 21: 273-275.

28. Rogul, M., J. J. Brendle, K. Haapala, and A. D. Alexander. 1970. Nucleic acid similarities among Pseudomonas pseudomallei, Pseudomonas multivorans and Actinobacillus mallei. J. Bacteriol. 101:827-835.

29. Scardovi, V., B. Sgorbati, and G. Zani. 1971 Starch gel electrophoresis of fructose-6-phosphate phosphoketolase in the genus Bifidobacterium. J. Bacteriol. 106:1036-1039.

30. Scardovi, V., and L. D. Trovatelli. 1974. Bifidobacterium animalis (Mitsuoka) comb. nov. and the "minimum" and "subtile" groups of new bifidobacteria found in sewage. Int. J. Syst. Bacteriol. 24:21-28.

31. Scardovi, V., L. D. Trovatelli, F. Crociani, and B. Sgorbati. 1969. Bifidobacteria in bovine rumen. New species of the genus Bifidobacterium: $B$. globosum $\mathrm{n}$. sp. and B. ruminale $\mathrm{n}$. sp. Arch. Mikrobiol. 68:278-294.

32. Scardovi, V., L. D. Trovatelli, G. Zani, F. Crociani, and D. Matteuzzi. 1971. Deoxyribonucleic acid homology relationships among species of the genus Bifidobacterium. Int. J. Syst. Bacteriol. 21:276-294.

33. Schleifer, K. M., and O. Kandler. 1973. Peptidoglycan types of bacterial cell walls and their taxonomic implications. Bacteriol. Rev. 36:407-477.

34. Schramm, M., V. Klybas, and F. Racker. 1958. Phosphorolytic cleavage of fructose-6-phosphate by fructose-6-phosphate phosphoketolase from Acetobacter xylinum. J. Biol. Chem. 233:1283-1288.

35. Sibley, J. A., and A. L. Lehninger. 1949. Determination of aldolase in animal tissues. J. Biol. Chem. 177:859-872. 